Downes, J. J., and Striker, T. W. (1966). Acta Anaesthesiologica Scandinavica, Suppl. No. 23, p. 747.

Downes, J. J., Striker, T. W., Wood, D. W., and Haddad, C. (1968). Anesthesiology, 29, 426 .

Dunnill, M. S. (1962). Thorax, 17, 329.

Elderkin, F. M., Gardner, P.' S., Turk, D. C., and White, A. C. (1965). British Medical fournal, 2,722 .

Gardner, P. S. (1973). Postgraduate Medical fournal, 49, 788.

Gardner, P. S., et al. (1967). British Medical fournal, 4, 316.

Gardner, P. S., McQuillin, J., and Court, S. D. M. (1970). British Medical fournal, $1,327$.

Gray, K. G., Macfarlane, D. E., and Sommerville, R. G. (1970). Lancet, 1, 446. Habel, A. H., and Inglis, J. M. (1974). In preparation.

Heycock, J. B., and Noble, T. C. (1956). British Medical fournal, 1, 438.

Heycock, J. B., and Noble, T. C. (1962). British Medical fournal, 2, 879

High, R. H. (1957). Pediatric Clinics of North America, 4, 183.

Hogg, J. C., Williams, J., Richardson, J. B., Macklem, P. T., and Thurlbeck, W. M. (1970) New England fournal of Medicine, 282, 1283.

Holzel, A., et al. (1963). Lancet, 1, 295.
Krieger, I. (1964). Pediatrics, 33, 45.

Loda, F. A., et al. (1968). Pediatrics, 72, 161.

McClelland, L., et al. (1961). New England fournal of Medicine, 164, 1169. McQuillin, J., Gardner, P. S., and Sturdy, P. M. (1970). Fournal of Hygiene,

68, 283.
Mansell, A., Bryan, C., and Levison, H. (1972). Fournal of Applied Physiology,

Meakins, J. C., and Davies, W. H. (1925). Respiratory Function in Disease. Edinburgh, Oliver and Boyd.

Nunn, J. F., Bergman, N. A., Coleman, A. J., and Casselle, D. C. (1964). British Yournal of Anaesthesia, 36, 666.

Reynolds, E. O. R. (1963). British Medical fournal, 1, 1192.

Severinghaus, J. W. (1966). Fournal of Applied Physiology, 21, 1108.

Severinghaus, J. W., and Bradley, A. F. (1969). Blood Gas Electrodes. C.V.R.I., University of California.

Simpson, H. (1973). M.D. thesis, University of Edinburgh

Simpson, H., and Flenley, D. C. (1967). Lancet, 1, 7.

Simpson, H., Matthew, D. J., George, E., and Habel, A. H. (1974). British Medical fournal, 2, 632

\title{
Acute Respiratory Failure in Bronchiolitis and Pneumonia in Infancy. Modes of Presentation and Treatment
}

H. SIMPSON,

D. J. MATTHEW,

A. H. HABEL,

E. L. GEORGE
British Medical fournal, 1974, 2, 632-636

\section{Summary}

The modes of presentation and the management of acute respiratory failure in 11 infants with severe lower respiratory tract infections (due to respiratory syncytial virus in eight) are described. Progressive respiratory difficulties leading to exhaustion, peripheral circulatory collapse, recurrent apnoeic attacks, or generalized convulsions were the main clinical presentations resulting in severe ventilatory failure. In nine infants preventilation carbon dioxide tensions exceeded $65 \mathrm{~mm} \mathrm{Hg}$. It seems likely that the use of intermittent positive-pressure ventilation in these patients contributed to the low mortality rate, less than $0.5 \%$, from such illnesses during the 15 -month study period.

\section{Introduction}

Every year some 3,000 children in the U.K. die from respiratory tract infection. Many of these deaths occur at home but even in hospital-based series the mortality rate is high (Disney et al., 1960; Heycock and Noble, 1962; Court, 1973). In more than a third of the cases predisposing disease or malformation is present (Court, 1973). Most affected infants respond satisfactorily to oxygen therapy, antibiotics, and general supportive measures. A few develop severe respiratory difficulties, however, and in these mechanical ventilation has been shown to be a major adjunct to treatment (Downes and Striker, 1966; Jones et al., 1968; Phelan et al., 1968). We have attempted to define the latter group with particular reference to its size, the mode of

University Department of Child Life and Health, Edinburgh H. SIMPSON, F.R.C.P., D.C.H., Part-time Senior Lecturer A. H. HABEL, M.B., M.R.C.P., Lecturer

Royal Hospital for Sick Children, Edinburgh EH9 1LF

D. J. MATTHEW, M.R.C.P., D.C.H., Registrar, Department of Paediatrics (now Registrar in Medical Paediatrics, Hospital for Sick Children, London WCW Registra

E. L. GEORGE, B.sc., Biochemist, Respiratory Intensive Care Unit presentation of the illness, and the relation of clinical and blood gas findings. The management of these patients is also described.

\section{Patients and Methods}

Out of 15 infants with bronchiolitis or pneumonia referred to the respiratory care unit of the Royal Hospital for Sick Children, Edinburgh, between 1 January 1972 and 31 March 1973, 11 were treated with intermittent positive-pressure ventilation (I.P.P.V.) using a mechanical ventilator. These infants represent some $3 \%$ of all infants under the age of 2 years admitted with acute lower respiratory tract infections during the same period. Their clinical details are given in table I. None had an associated congenital abnormality.

Respiratory distress, most prominent during feeds, and a dry, repetitive cough preceded by a coryzal phase were common initial symptoms; tachypnoea, retractions, and hyperinflation of the chest were the usual findings of the initial examination. Chest signs were bilateral, with areas of consolidation, collapse, or hypertranslucency to $x$ rays. Haemoglobin levels ranged from $9 \mathrm{~g}$ to $12 \mathrm{~g} / 100 \mathrm{ml}$ and only one patient had a white blood cell count exceeding $15,000 / \mathrm{mm}^{3}$ (case 11 , W.B.C. $25,000 / \mathrm{mm}^{3}$; neutrophils $73 \%$, lymphocytes $22 \%$ ). Serum sodium, potassium, chloride, and urea nitrogen concentrations were within normal limits in the eight patients in whom measurements were made before rehydration. E.C.G. showed no evidence of myocarditis in the nine patients studied at the height of their illness. Escherichia coli, Haemophilus influenzae, and Staphylococcus aureus, isolated in cases 2,6 , and 8 respectively, were the sole bacterial pathogens found in nasal and throat swabs. Coliforms (cases 2 , 6, and 10), pneumococci (case 7), and Pseudomonas aeruginosa (case 8) were isolated from bronchial secretions obtained at the time of nasotracheal intubation. No organism was isolated from blood cultures. There was evidence of infection with respiratory syncytial virus (R.S.V.) in eight out of 10 infants studied (cases $1,3,4$ and $7-11$; table I). In all cases serum concentrations of IgA IgM, and IgG were within normal limits for age (Stiehm and Fudenberg, 1966).

Two patients were treated with corticosteroids before I.P.P.V. (cases 2 and 11) and five were digitalized (cases 1, 4, 6, 7, and 11). Correction and maintenance of fluid and electrolyte balance was achieved by tube-feeding or parenteral replacement. Intravenous infusion of sodium bicarbonate $(8.4 \%)$ preceded I.P.P.V. in cases $2,4,6$, and 8 . 
TABLE I-Clinical Details of Patients on Admission

\begin{tabular}{|c|c|c|c|c|c|c|c|c|}
\hline \multirow{2}{*}{ Case No. } & \multirow{2}{*}{$\begin{array}{c}\text { Sex and } \\
\text { Age } \\
\text { (Months) }\end{array}$} & \multirow{2}{*}{$\begin{array}{c}\text { Weight } \\
\text { (kg) }\end{array}$} & \multirow{2}{*}{$\begin{array}{c}\text { Previous } \\
\text { Respiratory } \\
\text { Illness }\end{array}$} & \multirow{2}{*}{$\begin{array}{c}\text { History } \\
\text { (Days) }\end{array}$} & \multirow{2}{*}{$\begin{array}{c}\text { Previous } \\
\text { Antibiotics }\end{array}$} & \multicolumn{2}{|c|}{$\begin{array}{l}\text { Clinicoradiological } \\
\text { Diagnosis }\end{array}$} & \multirow{2}{*}{ Outcome } \\
\hline & & & & & & Initial & Final & \\
\hline $\begin{array}{r}1 \\
2 \\
3 \\
4 \\
5 \\
6 \\
7 \\
8 \\
9 \\
10\end{array}$ & $\begin{array}{l}\text { F. } 2 \\
\text { F. } 4 \\
\text { M. } 2.5 \\
\text { F. } 1.5 \\
\text { M. } 1.5 \\
\text { F. } 3 \\
\text { M. } 8 \\
\text { M. } 1.5 \\
\text { F. } 1.5 \\
\text { F. } 1.5\end{array}$ & $\begin{array}{l}2 \cdot 5 \\
4 \cdot 6 \\
6 \cdot 6 \\
3 \cdot 7 \\
5 \cdot 4 \\
4 \cdot 0 \\
9 \cdot 0 \\
5 \cdot 6 \\
2 \cdot 5 \\
2 \cdot 5\end{array}$ & $\begin{array}{l}\text { L.R.T.I. } \\
\text { U.R.T.I. } \\
\text { L.R.T.I. } \\
\text { U.R.T.I. } \\
\text { I.R.D.S. }\end{array}$ & $\begin{array}{l}2 \\
4 \\
7 \\
3 \\
3 \\
4 \\
5 \\
4 \\
2 \\
4\end{array}$ & $\begin{array}{l}\text { Penicillin } \\
\text { Ampicillin } \\
\text { Erythromycin } \\
\text { Ampicillin } \\
\text { Erythromycin } \\
\text { Penicillin } \\
\text { Penicillin } \\
\text { Penicillin } \\
\text { Penicillin, } \\
\text { ampicillin }\end{array}$ & $\begin{array}{l}\text { B. } \\
\text { B.P. } \\
\text { B. } \\
\text { B. } \\
\text { B. } \\
\text { B. } \\
\text { B. } \\
\text { B. } \\
\text { B.P. } \\
\text { B.P. }\end{array}$ & $\begin{array}{l}\text { B.P. } \\
\text { B.P. } \\
\text { B. } \\
\text { B.P. } \\
\text { B.P. } \\
\text { B.P. } \\
\text { B.P. } \\
\text { B.P. } \\
\text { B.P. } \\
\text { B.P. }\end{array}$ & $\begin{array}{l}\text { S. } \\
\text { S. } \\
\text { S. } \\
\text { S. } \\
\text { D. } \\
\text { S. } \\
\text { S. } \\
\text { S. }\end{array}$ \\
\hline 11 & M. 10 & $10 \cdot 0$ & L.R.T.I. & 1 & Ampicillin & L.P. & L.P. & s. \\
\hline
\end{tabular}

L.R.T.I. = Lower respiratory tract infection. U.R.T.I. = Upper respiratory tract infection. I.R.D.S. $=$ Idiopathic respiratory distress syndrome.

B. = Bronchiolitis. B.P.= Bronchopneumonia. L.P. = Lobar pneumonia. S. = Survived. D. = Died.

The virological and blood gas analytical methods are described in our accompanying paper (Simpson et al., 1974).

\section{Results}

Nine of the 11 infants treated with I.P.P.V. were under the age of 6 months. R.S.V. was the main pathogen found but was not isolated from the infant who died (case 6). Before admission to hospital noisy or distressed breathing was common to all patients. Four clinical patterns later emerged: progressive respiratory difficulty culminating in severe respiratory failure (cases $1,3,4$, $5,6,7$, and 8), peripheral circulatory collapse (cases 2 and 11), recurrent apnoeic attacks (cases 4,9 , and 11 ), and generalized convulsions (case 11). The individual acid-base values at various stages of the illness in these infants both before and after assistance with ventilation are set out in table II. Peak values relate to the highest carbon dioxide tensions $\left(\mathrm{PCO}_{2}\right)$ before I.P.P.V.-in all cases I.P.P.V. was begun within the next hour. Ventilation was used in cases 1-9 because of severe ventilatory failure, and in case 10 for episodes of apnoea during which the patient became grey, mottled, and limp and developed severe bradycardia. In case 11 the patient was intubated to maintain a clear airway after a generalized convulsion at a time when moderate ventilatory failure $\left(\mathrm{PcO}_{2} 57 \mathrm{~mm} \mathrm{Hg}\right)$ was present. The clinical course in case 6 was complicated by cardiac arrest and severe cerebral anoxia resulting from accidental extubation at a stage when recovery seemed likely. The patient was ventilated for a further eight days and survived several weeks before dying from a further episode of infection.

The different modes of clinical presentation and the effectiveness of I.P.P.V. in restoring normal ventilation and preventing asphyxia are illustrated by the following case reports. R.S.V. was the main pathogen in each case.

\section{CASE REPORTS}

Case 2.-This 4-month-old infant (fig. 1) presented with four days of coryzal symptoms and a one-day history of respiratory distress and pallor. She was admitted direct to the respiratory care unit on aocount of severe pallor, tachycardia, tachypnoea, and grunting respirations. Chest $x$-ray examination showed extensive bilateral bronchopneumonia. Despite a normal $\mathrm{pH}$ and $\mathrm{PCO}_{2}$ initially and treatment with $40-50 \%$ oxygen peripheral circulatory collapse followed an apnoeic episode some hours later. She was resuscitated successfully and ventilated mechanically for five days. Subsequent progress was uneventful and she made a complete recovery.

Case 4.-This 6-week-old infant (fig. 2) was admitted to hospital with a three-day history of wheeze and breathlessness. She was not unduly distressed initially and chest $x$-ray examination showed only hyperinflation of the lung fields. She became increasingly distressed over the next 24 hours and developed recurrent apnoeic attacks associated with bradycardia and cyanosis. Initial (arterialized capillary) blood gas tensions were indicative of severe ventilatory failure, later confirmed by arterial samples. She was transferred to the respiratory care unit and treated with I.P.P.V. for four days. She made an uneventful recovery.

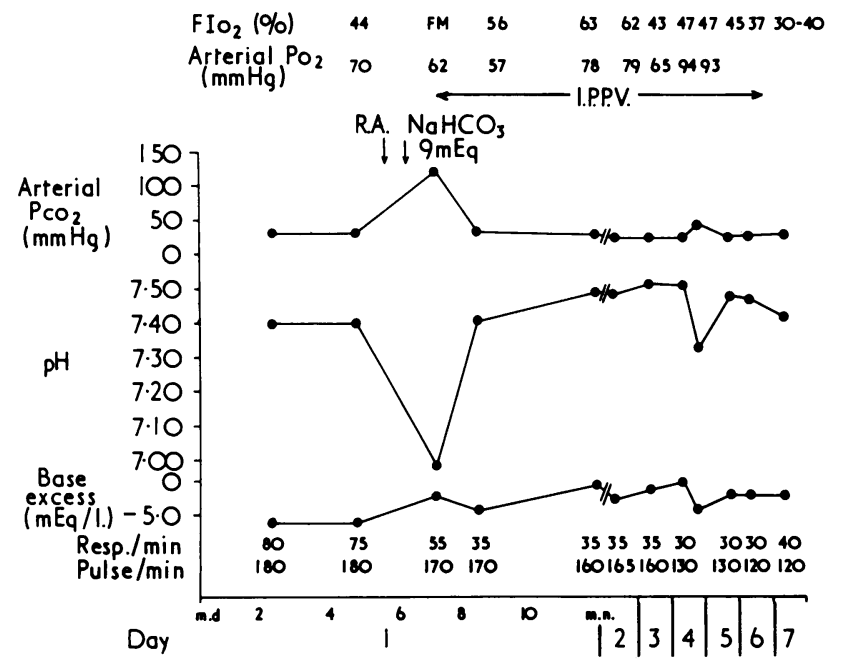

FIG. 1-Case 2. Sequential blood gas tensions and pH (before, during, and after I.P.P.V.) in 4-month-old infant with severe bronchopneumonia. Peripheral circulatory collapse followed brief period of respiratory arrest (R.A.). $\mathrm{FIO}_{2}$ Fractional inspired oxygen concentration.

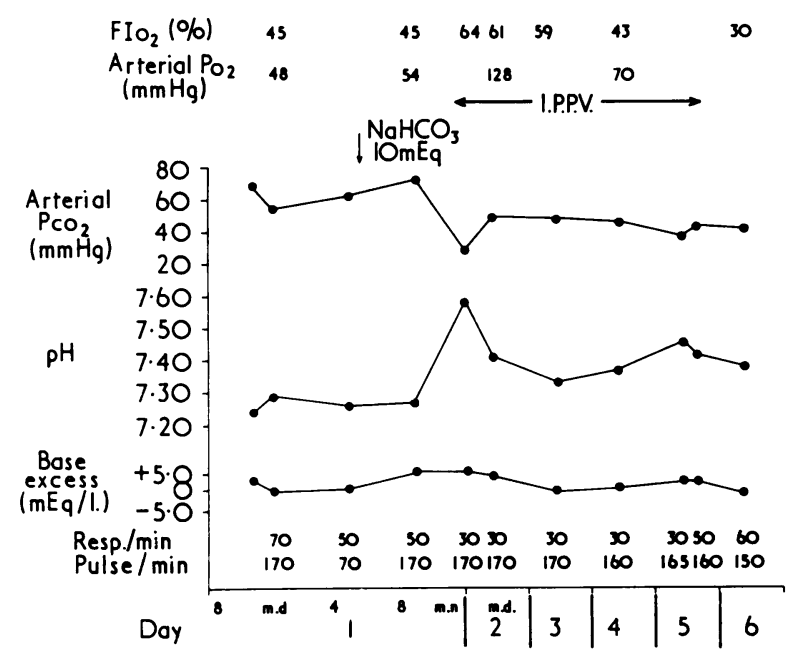
FIG. 2-Case 4. Sequential blood gas tensions and $\mathrm{pH}$ in 5 -week-old infant
with recurrent attacks of apnoea and severe ventilatory failure due to bronwith recurrent 
Case 8.-This 6-week-old infant (fig. 3) was admitted with a four-day history of cough and wheeziness. A diagnosis of bronchiolitis was made on admission and he was nursed in $40 \%$ oxygen. Chest $x$-ray examination showed hyperinflation of both lung fields. Over the next 24 hours he became increasingly distressed and almost exhausted. He was treated with I.P.P.V. for 14 days. During this period he developed secondary bronchopneumonia due to Ps. aeruginosa but responded to treatment with carbenicillin and gentamicin. Tracheostomy was performed after eight days. Extubation proved simple and he made a complete recovery.

Case 11.-This 10-month-old infant (fig. 4) was admitted to hospital with oough and breathlessness of one day's duration. He was moderately distressed clinically and chest $x$-ray examination showed areas of collapse or consolidation in the right upper and middle lobes. His condition steadily deteriorated until after 12 hours he suddenly had a generalized convulsion with "decerebrate" posturing. The anterior fontanelle was tense, a cranial bruit was readily heard, and he had bilateral papilloedema. He was treated with $20 \%$ mannitol, hydrocortisone, diazepam, and intravenous sodium bicarbonate. A nasotracheal tube was passed to ensure a clear airway and he was ventilated mechanically. Improvement was rapid and clear sterile C.S.F. was obtained by lumbar puncture after the intracranial pressure had been reduced. He could not be weaned off the ventilator for a further five days. He later recovered.

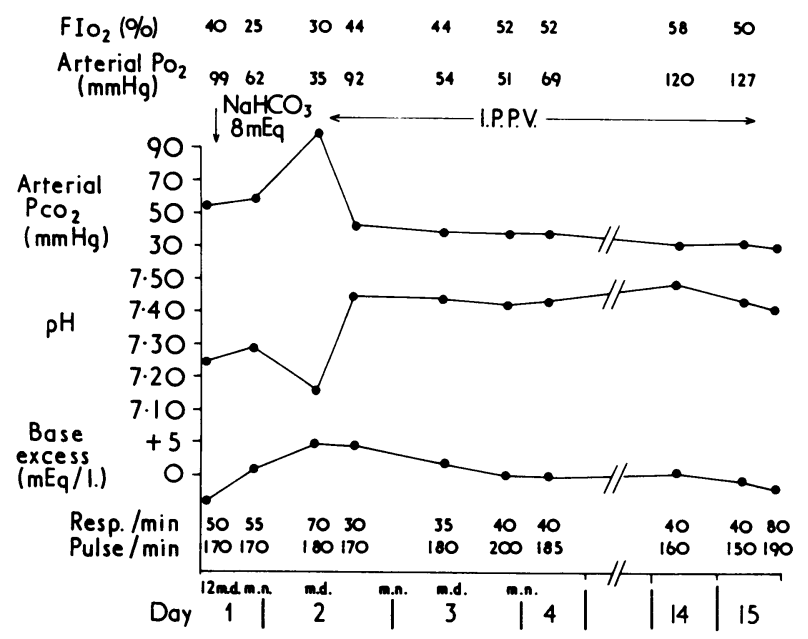

FIG. 3-Case 8. Sequential blood gas tensions and $\mathrm{pH}$ during course of bronchopneumonia in 6-week-old infant who became progressively exhausted and developed severe ventilatory failure.

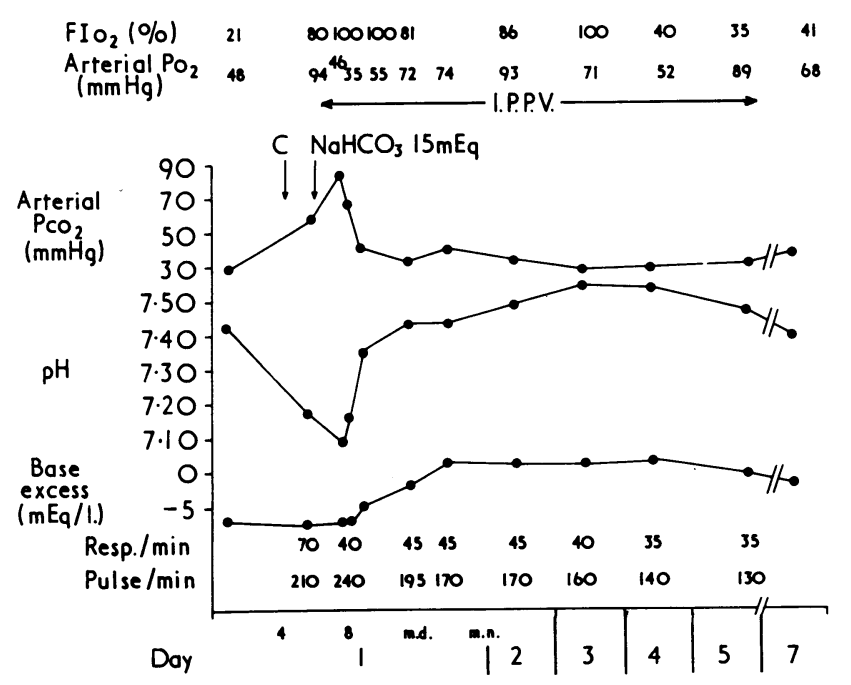

FIG. 4-Case 11. Sequential blood gas tensions and pH during course of pneumonia in 10-month-old infant. Generalized convulsion (C) with increased intracranial pressure and "decerebrate" posturing was associated with worsening respiratory failure.

\section{Clinical Management of Respiratory Failure}

We use the following scheme of management. Patients admitted with bronchiolitis or pneumonia are nursed in 30-50\% humidified oxygen in tents or head boxes. Inspired oxygen concentration is checked periodically. Arterialized capillary blood samples are obtained initially from moderately and severely distressed patients breathing air or $40 \%$ oxygen; arterial samples are taken to ensure greater precision, particularly with respect to oxygen tension to $\left(\mathrm{Po}_{2}\right)$, when $\mathrm{Po}_{2}$ is greater than $50 \mathrm{~mm} \mathrm{Hg}$ or $\mathrm{pH}$ is less than $7 \cdot 30$. Subsequent measurements are determined by the initial findings and clinical progress. During the acute phase many infants are tube-fed but the most severely ill are rehydrated with intravenous infusions of $0.45 \%$ saline and $5 \%$ dextrose. Maintenance volumes of $100 \mathrm{ml} / \mathrm{kg} /$ day are usually given (Holliday and Segar, 1957) but during I.P.P.V. a reduction to $50-80 \mathrm{ml} / \mathrm{kg} /$ day is often necessary to prevent clinical signs of overhydration.

Intravenous sodium bicarbonate $8.4 \%$ is infused slowly over two to three minutes when base excess exceeds $-6 \mathrm{mEq} / \mathrm{l}$. Steroids are not used routinely (Leer et al., 1969) but hydrocortisone is given for acute circulatory collapse. Though most patients do not show convincing evidence of cardiac failure digoxin is given whenever the pulse rate exceeds $180-200 / \mathrm{min}$ with progressive enlargement of the liver. Ampicillin $50 \mathrm{mg} / \mathrm{kg} /$ day and cloxacillin $50 \mathrm{mg} / \mathrm{kg} /$ day are prescribed for many infants because of our inability to exclude a bacterial aetiology clinically. The decision to ventilate is made on the basis of clinical assessment and measurement of blood gas tensions. In this series the main indication in cases 1 to 9 was severe ventilatory failure $\left(\mathrm{PCO}_{2} 65-70 \mathrm{~mm} \mathrm{Hg}\right)$. Recurrent apnoeic attacks and generalized seizures causing severe hypoxaemia were the main considerations in the remaining two cases.

The treatment of acute respiratory failure in bronchiolitis and bronchopneumonia by nasotracheal intubation, tracheostomy, and mechanical ventilation has been the subject of earlier reports (Downes and Striker, 1966; Downes et al., 1968, 1972; Joly et al., 1967; Jones et al., 1968). Our techniques were similar in principle to those described. Affected infants were nursed under a radiant heat source and the E.C.G. was monitored continuously. Constant nursing care was maintained throughout the entire period of I.P.P.V. The trachea was intubated through the mouth and after tracheobronchial toilet and manual hyperinflation of the lungs nasotracheal intubation was performed electively using a Jackson-Rees polyvinyl tube of appropriate size (Rees and Owen-Thomas, 1966). Pancuronium bromide $0.1 \mathrm{mg} / \mathrm{kg}$ intravenously preceded oral intubation and was given every two to three hours intravenously or intramuscularly as necessary. Diazepam $0.1 \mathrm{mg} / \mathrm{kg}$ intravenously in repeated doses was used to maintain sedation and at a later stage was often effective on its own in maintaining depression of the respiratory centre.

Mechanical ventilation was provided by the Amsterdam (Loosco) time-flow preset ventilator at a respiratory rate of $30-40 / \mathrm{min}$. An inspiratory :expiratory time ratio of $1: 1$ and a flow rate usually twice that predicted by calculation (assuming a tidal volume of $6 \mathrm{ml} / \mathrm{kg}$ ) were used initially. Most reliance was placed, however, on visual and auscultatory evidence of ventilation; during the next few hours gas flow was adjusted on the basis of repeated blood gas analysis. The desired oxygen concentration, usually $60-80 \%$ at first, was achieved by admixing centrally supplied air and oxygen using back-pressure-compensated flow meters. Acid-base variables were measured once or twice daily once stability had been achieved. To ensure adequate humidification sterile saline $1-2 \mathrm{ml}$ was instilled into the trachea at intervals of 30 minutes to one hour and airway suction was carried out over a period of 10-20 seconds. An end-hole suction catheter was used and inserted to maximum depth into alternate bronchi, suction being applied only during withdrawal (Young and Crocker, 1970).

Most infants improved gradually over two to four days, by which time normal $\mathrm{PCO}_{2}$ and $\mathrm{Po}_{2}$ levels could usually be achieved 
with inspiratory pressures near $20 \mathrm{~cm}$ of water and an inspired oxygen concentration of $40 \%$ or less. Attempts were then made to wean infants from the ventilator over a period of 6-12 hours. Extubation was attempted only when the $\mathrm{PCO}_{2}$ remained below $45 \mathrm{~mm} \mathrm{Hg}$ after six hours of spontaneous breathing. In five patients tracheostomy was substituted for nasotracheal intubation after seven days (cases $1,6,8,9$, and 10). The tracheostomy tube was removed as soon as possible after successful weaning from the ventilator. In case 10 extubation was possible only after eight months.

The complications of acute respiratory failure in children have been fully reviewed (Downes et al., 1972). Accidental extubation was the most alarming complication in the present series and was the primary cause of death in one patient (case 6). Other problems were pneumothorax, atelectasis, right upper lobe consolidation, secondary bacterial bronchopneumonia, and a host of minor mechanical difficulties. With increasing experience most of these hazards could be averted or dealt with quickly and effectively at an early stage.

\section{Discussion}

The infants treated by I.P.P.V. constituted some $3 \%$ of all the infants under the age of 2 years admitted to hospital with acute lower respiratory tract infection. All were severely ill and survival with conservative treatment alone seemed unlikely. Progressive respiratory difficulties leading to exhaustion, circulatory collapse, convulsions, and recurrent apnoeic attacks are well recognized preterminal events (Disney et al., 1960; Elderkin et al., 1965; Gardner et al., 1967; Simpson, 1973) but have not been closely correlated with measurements of blood gas tensions and $\mathrm{pH}$. In a series of 70 infants with bronchopneumonia, Jones et al. (1968) described three main modes of presentationrespiratory failure, circulatory failure, and staphylococcal pneumonia. Our experience confirms their assertion that in "the majority of infants with severe bronchopneumonia the illness begins with respiratory symptoms and may progress to respiratory failure." In the present series there were no definite cases of staphylococcal pneumonia, and circulatory collapse occurred in only one patient (case 2)-a sequel to respiratory arrest.

Respiratory failure as defined by Campbell (1965) was common to all cases irrespective of the mode of clinical presentation, and in nine patients the $\mathrm{PCO}_{2}$ exceeded $65 \mathrm{~mm} \mathrm{Hg}$. This degree of ventilatory failure was not always present on admission to hospital. Progressive deterioration over a variable time period occurred in many such cases (table II), and this confirms the importance of clinical vigilance even in mild to moderately severe cases.

Reynolds (1963) showed that there was a significant inverse relation between respiratory rate and arterial oxygen tension and that respiratory rates exceeding $60 / \mathrm{min}$ were usually associated with carbon dioxide retention in a group of infants with bronchiolitis. In a study of 32 infants under 3 years of age with acute lower respiratory tract infections, however, Simpson and Flenley (1967) stressed that clinical signs of respiratory distress were poor indicators of blood gas tensions in individual cases. Cyanosis, invariably present when oxygen saturation was below $85 \%$, was a late but reliable sign of hypoxia. A diminished level of consciousness (little response to pinching the skin or pricking the soles) is often present at a $\mathrm{pH}$ below $7 \cdot 30$ (Simpson 1973). Under ideal circumstances we recommend the measurement of "arterialized" capillary blood gas tensions and $\mathrm{pH}$ in all infants presenting with acute lower respiratory tract infections either in air or in $40 \%$ oxygen depending on clinical severity. In practice a rising respiration or pulse rate (particularly a respiration rate greater than $60 / \mathrm{min}$ or a pulse rate more than $150 / \mathrm{min}$ or both), cyanosis in air, or pronounced retractions occurring singly or in combination are definite indications of blood gas monitoring.

Previous experience (Simpson and Flenley, 1967) and the studies of Downes et al. (1968) support the contention that these infants were in a parlous state. In eight cases reported by Simpson and Flenley (1967) arterial $\mathrm{pH}$ was less than 7.20 and $\mathrm{PCO}_{2}$ was greater than $65 \mathrm{~mm} \mathrm{Hg}$ when studied initially; three

\begin{tabular}{|c|c|c|c|c|c|c|c|c|}
\hline \multirow[b]{3}{*}{ Case No. } & \multicolumn{8}{|c|}{ Before I.P.P.V. } \\
\hline & \multicolumn{4}{|c|}{ Initial } & \multicolumn{4}{|c|}{ Peak } \\
\hline & $\mathrm{pH}$ & $\begin{array}{c}\mathrm{Pco}_{\mathbf{2}} \\
(\mathrm{mm} \mathrm{Hg})\end{array}$ & $\begin{array}{c}\text { Base } \\
\text { Excess } \\
(\mathrm{mEq} / 1 .) \\
\end{array}$ & $\begin{array}{l}\text { Time* } \\
\text { (Days) }\end{array}$ & $\begin{array}{c}\mathrm{PcO}_{2} \\
\mathrm{pH}\end{array}$ & $\begin{array}{c}\mathrm{PCO}_{\mathbf{g}} \\
(\mathbf{m m ~ H g})\end{array}$ & $\begin{array}{c}\text { Base } \\
\text { Excess } \\
(\mathrm{mEq} / 1 .) \\
\end{array}$ & $\begin{array}{c}\text { Time } \\
(\mathbf{H r})\end{array}$ \\
\hline $\begin{array}{l}1 \\
2 \\
3 \\
4 \\
5 \\
6 \\
7 \\
8 \\
9\end{array}$ & $\begin{array}{l}7 \cdot 25 \\
7.40 \\
7.29 \\
7.24 \\
7.27 \\
7.19 \\
7.37 \\
7.25 \\
7.43\end{array}$ & $\begin{array}{l}45 \\
30 \\
49 \\
71 \\
77 \\
50 \\
37 \\
52 \\
35\end{array}$ & $\begin{array}{l}-6.8 \\
-6.4 \\
-2.6 \\
+3.0 \\
+8.0 \\
-8.2 \\
-3.6 \\
-3.8 \\
-1.0\end{array}$ & $\begin{array}{l}2 \\
1 \\
1 \\
2 \\
3 \\
1 \\
2 \\
2 \\
1\end{array}$ & $\begin{array}{l}7 \cdot 20 \\
6.99 \\
7 \cdot 28 \\
7 \cdot 27 \\
7 \cdot 24 \\
7.16 \\
7.33 \\
7 \cdot 16 \\
7 \cdot 21 \\
\end{array}$ & $\begin{array}{r}83 \\
120 \\
65 \\
73 \\
85 \\
75 \\
66 \\
95 \\
78 \\
\end{array}$ & $\begin{array}{l}+4.3 \\
-2.6+ \\
+2.8 \\
+6.3 \dagger \\
+8.5 \\
-1.6 \dagger \\
+8.7 \\
+5.0 \dagger \\
+3.5\end{array}$ & $\begin{array}{r}41 \\
5 \\
17 \\
10 \\
3 \\
4 \\
250 \\
21 \\
35\end{array}$ \\
\hline Mean \pm S.D. & $7.30 \pm 0.08$ & $49.6 \pm 15 \cdot 8$ & $-2.4 \pm 5 \cdot 1$ & & $7 \cdot 20 \pm 0.10$ & $82.0 \pm 17.3$ & $+3.9 \pm 4.0$ & \\
\hline \multirow[t]{3}{*}{$\begin{array}{l}10 \\
11\end{array}$} & $\begin{array}{l}7 \cdot 29 \\
7 \cdot 41\end{array}$ & $\begin{array}{l}47 \\
27\end{array}$ & $\begin{array}{l}-3.7 \\
-7.5\end{array}$ & $\begin{array}{l}1 \\
1\end{array}$ & $\begin{array}{l}7 \cdot 37 \\
7 \cdot 17\end{array}$ & $\begin{array}{l}49 \\
57\end{array}$ & $\begin{array}{l}+3.0 \\
-7.5\end{array}$ & $\begin{array}{l}5 \\
5\end{array}$ \\
\hline & \multicolumn{8}{|c|}{ I.P.P.V. } \\
\hline & \multicolumn{4}{|c|}{ Improved } & \multicolumn{4}{|c|}{ Weaning } \\
\hline Case No. & pH & $\underset{(\mathrm{mm} \mathrm{Hg})}{\mathrm{Pco}_{\mathbf{2}}}$ & $\begin{array}{c}\text { Base } \\
\text { Excess } \\
\text { (mEq/1.) }\end{array}$ & $\begin{array}{c}\text { Time§ } \\
(\mathbf{H r})\end{array}$ & $\mathrm{pH}$ & $\begin{array}{c}\mathrm{Pco}_{\mathbf{2}} \\
(\mathrm{mm} \mathrm{H} \mathbf{~})\end{array}$ & $\begin{array}{c}\text { Base } \\
\text { Excess } \\
(\mathrm{mEq} / 1 .) \\
\end{array}$ & $\begin{array}{l}\text { Time11 } \\
\text { (Days) }\end{array}$ \\
\hline $\begin{array}{l}1 \\
2 \\
3 \\
4 \\
5 \\
6 \\
7 \\
8 \\
9 \\
\end{array}$ & $\begin{array}{l}7.42 \\
7.41 \\
7.35 \\
7.41 \\
7.41 \\
7.32 \\
7.48 \\
7.44 \\
7.43\end{array}$ & $\begin{array}{l}42 \\
32 \\
50 \\
48 \\
49 \\
60 \\
37 \\
42 \\
43\end{array}$ & $\begin{array}{l}+2.8 \\
-4.2 \\
+2.0 \\
+5.5 \\
+6.0 \\
+4.8 \\
+4.0 \\
+4.3 \\
+4.4\end{array}$ & $\begin{array}{r}4 \\
1 \\
2 \\
11 \\
9 \\
1 \\
2 \\
5 \\
3\end{array}$ & $\begin{array}{l}7.37 \\
7.47 \\
7.43 \\
7.42 \\
7.45 \\
7.33 \\
7.42 \\
7.41 \\
7.41 \\
\end{array}$ & $\begin{array}{l}41 \\
28 \\
40 \\
43 \\
40 \\
46 \\
38 \\
34 \\
37\end{array}$ & $\begin{array}{l}-1.2 \\
-3.1 \\
+2.0 \\
+3.5 \\
+3.7 \\
-1.6 \\
+0.2 \\
-3.0 \\
-1.0\end{array}$ & $\begin{array}{r}10 \\
5 \\
6 \\
4 \\
2 \\
14 \\
4 \\
13 \\
8\end{array}$ \\
\hline Mean \pm S.D. & $7.41 \pm 0.05$ & $44 \cdot 8 \pm 8 \cdot 1$ & $+3.3 \pm 3.1$ & & $7.41 \pm 0.04$ & $38 \cdot 6 \pm 5 \cdot 2$ & $-0.05 \pm 2.6$ & \\
\hline $\begin{array}{l}10 \\
11\end{array}$ & $\begin{array}{l}7.39 \\
7.33 \\
\end{array}$ & $\begin{array}{l}44 \\
40 \\
\end{array}$ & $\begin{array}{l}+1.7 \\
-4.5+\end{array}$ & $\begin{array}{r}10 \\
2 \\
\end{array}$ & $\begin{array}{l}7.35 \\
7.47 \\
\end{array}$ & $\begin{array}{l}41 \\
31 \\
\end{array}$ & $\begin{array}{l}-2.5 \\
-1.5 \\
\end{array}$ & $\begin{array}{l}7 \\
5 \\
\end{array}$ \\
\hline
\end{tabular}


patients died, including two treated terminally by I.P.P.V. In a study of five infants with severe bronchiolitis, Downes et al. (1968) showed a striking increase in the dead space to tidal volume ratios and a twofold to threefold increase in minute volume at a $\mathrm{PCO}_{2}$ below $65 \mathrm{~mm} \mathrm{Hg}$. With progressive fatigue the minute volume fell to predicted basal levels and $\mathrm{PCO}_{2}$ rose above $65 \mathrm{~mm} \mathrm{Hg}$. At that stage most infants were severely distressed clinically but recovered after nasotracheal intubation, neuromuscular blockage, and mechanical ventilation.

Our management techniques differ little from those described previously. Though these were important perhaps the major determinant of effective and safe mechanical ventilation was the provision of adequate facilities, the close co-operation of medical, anaesthetic, and laboratory personnel, and continuous skilled nursing. When these conditions are not present the hazards of mechanical ventilation increase sharply.

In recent years there has been an encouraging fall in the number of deaths from pneumonia in our hospital despite an increase in the number of patients admitted with acute lower respiratory tract infection (12-14\% of the total admissions). This is illustrated in fig. 5 , which shows that the number of otherwise normal children dying of bronchiolitis or pneumonia has fallen to 10 in the past six years, compared with 18 and 28 in the preceding two five-year periods. An analysis of the deaths

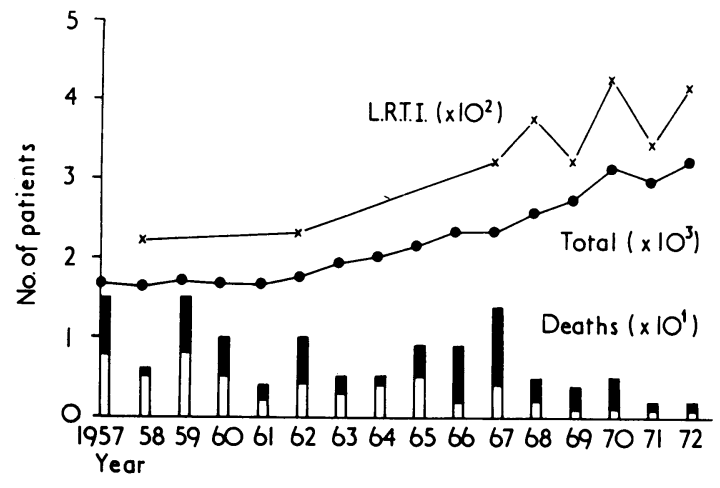

FIG. 5-Acute lower respiratory tract infection (L.R.T.I.). Admissions and deaths in relation to total medical admissions during 1957 to 1972 . Shaded areas represent presence of predisposing cause or congenital abnormality (excludes cystic fibrosis). Open areas represent no predisposing cause or congenital abnormalities present. Age distribution of the 56 patients in whom no predisposing cause or congenital abnormality was present was as follows: $<1$ month, $15 ; 1-6$ months, $33 ; 6$ months to 1 year, $4 ;>1$ year, 4 . Necropsy was performed in 46 . occurring between 1957 and 1966 is given elsewhere (Simpson, 1973). Facilities for blood gas analysis were first available in 1966 but a realistic 24-hour service was not introduced until 1970 , before the opening of the respiratory care unit. Infants with pneumonia represent less than $25 \%$ of those admitted to this unit for treatment of respiratory failure. As it is extremely expensive to provide an optimal service we agree with Downes et al. (1972) that such a service should not necessarily be duplicated in every hospital. Consideration should be given to the distribution of paediatric respiratory intensive care and the safe transportation of patients to such centres.

We wish to thank Professor J. O. Forfar for his support and encouragement, Dr. D. J. Grubb and Dr. R. Burtles for advice and help in ventilating these children, and the physicians at the Royal Hospital for Sick Children, Edinburgh, who referred patients under their care. Our thanks are also due to the nursing staff of the respiratory care unit for their excellent standard of nursing care, and to laboratory staff who provided the blood gas servioe.

\section{References}

Campbell, E. J. M. (1965). British Medical fournal, 1, 1451. Disney, M. E., Sandiford, B. R., Cragg, J., and Wolff, J. (1960). British

Downes, J. J., and Striker, T. W. (1966). Acta Anaesthesiologica Scandinavica, Suppl. no. 23, p. 747.

Downes, J. J., Striker, T. W., Wood, D. W., and Haddad, C. (1968). Anesthesiology, 29, 426.

Downes, J. J., Fulgencio, T., and Raphaely, R. C. (1972). Pediatric Clinics of North America, 19, 423.

Elderkin, F. M., Gardner, P. S., Turk, D. C., and White, A. C., (1965). British Medical fcurnal, 2,722 .

Gardner, P. S., et al. (1967). British Medical fournal, 4, 316.

Heycock, J. B., and Noble, T. C. (1962). British Medical fournal, 2, 879.

Holliday, M. A., and Segar, W. E. (1957). Pediatrics, 19, 823.

Joly, J. B., Huault, G., Amsill, J., Lemerle, J., and Thieffry, S. (1967). Archives Françaises de Pédiatrie, 24, 303.

Jones, R. S., Owen-Thomas, J. B., and Boulton, M. J. (1968). Archives of Disease in Childhood, 43, 415.

Leer, J. A., et al. (1969). American fournal of Diseases of Children, 117, 495. Phelan, P. D., Williams, H. E., Stocks, J. G., and Freeman, M. (1968). Australian Paediatric fournal, 4, 223.

Rees, G. J., and Owen-Thomas, J. B. (1966). British fournal of Anaesthesia, 38,901 .

Reynolds, E. O. R. (1963). Fournal of Pediatrics, 63, 1135.

Simpson, H. (1973). M.D. thesis, University of Edinburgh.

Simpson, H., and Flenley, D. C. (1967). Lancet, $1,7$.

Simpson, H., Matthew, D. J., Inglis, J. M., and George, E. L. (1974). British Medical fournal, $2,629$.

Stiehm, E. R., and Fudenberg, H. H. (1966). Pediatrics, 37, 715.

Young, J. A., and Crocker, D. (1970). Principles and Practice of Inhalation Therapy. Chicago, Year Book Medical Publishers Inc.

\footnotetext{
McIndoe Research Unit, Queen Victoria Hospital, East Grinstead,

Sussex
HELEN M. CHAPEL, M.B., B.CHIR., Research Assistant (Present address

Department of Experimental Pathology, Medical School, University of Birmingham, Birmingham B15 2TJ)

J. R. BATCHELOR, M.D., Director of Unit.
}

inhibitory concentration of antihuman lymphocyte globulin needed to inhibit rosette formation by $25 \%$ was specifically associated with rejection of such a graft. No such change was observed.

\section{Introduction}

A high proportion of human lymphocytes will react with sheep red blood cells to form spontaneous rosettes (Jondal et al., 1972; Chapel, 1973). This rosette formation has been shown to be inhibited by high dilutions of antihuman lymphocyte globulin (A.L.G.) (Bach et al., 1969), and an in-vitro test based on this inhibition has been described (Munro et al., 1971). It has been suggested that this rosette inhibition test, despite its obscure immunological basis, is a measure of the immunosuppression of 